\title{
Effect of applying inoculants with heterolactic or homolactic and heterolactic bacteria on the fermentation and quality of corn silage
}

\author{
K. G. Arriola, S. C. Kim, ${ }^{1,2}$ and A. T. Adesogan \\ Department of Animal Sciences, Institute of Food and Agricultural Sciences, University of Florida, Gainesville 32608
}

\begin{abstract}
This study examined the effect of applying different bacterial inoculants on the fermentation and quality of corn silage. Corn plants were harvested at $35 \%$ DM, chopped, and ensiled in 20-L mini silos after application of (1) deionized water $(\mathrm{CON})$ or inoculants containing (2) $1 \times 10^{5} \mathrm{cfu} / \mathrm{g}$ of Pediococcus pentosaceus 12455 and Propionibacteria freudenreichii (B2); (3) $4 \times 10^{5} \mathrm{cfu} / \mathrm{g}$ of Lactobacillus buchneri 40788 (BUC); or (4) $1 \times 10^{5}$ $\mathrm{cfu} / \mathrm{g}$ of Pediococcus pentosaceus 12455 and $4 \times 10^{5}$ cfu/g of L. buchneri 40788 (B500). Four replicates of each treatment were weighed into polyethylene bags within 20-L mini silos. Silos were stored for $575 \mathrm{~d}$ at ambient temperature $\left(25^{\circ} \mathrm{C}\right)$ in a covered barn. After silos were opened, aerobic stability, chemical composition, and yeast and mold counts were determined. The DNA in treated and untreated silages was extracted using lysozyme/sodium dodecyl sulfate lysis and phenol/ chloroform and used as a template for a conventional PCR with primers designed on the $16 \mathrm{~S}$ rRNA gene to detect the presence of L. buchneri in all silage samples. Acetic acid concentration was greater in B2 silages versus others (6.46 vs. $4.23 \%$ DM). Silages treated with BUC and B500 had lower $\mathrm{pH}$ and propionic acid concentration and greater lactic acid concentration than others. The B500 silage had the greatest lactic:acetic acid ratio (1.54 vs. 0.41), and only treatment with BUC reduced DM losses (5.0 vs. $14.3 \%$ ). Yeast and mold counts were less than the threshold $\left(10^{5}\right)$ typically associated with silage spoilage and did not differ among treatments. Consequently, all silages were very stable $(>250 \mathrm{~h})$. Aerobic stability was not improved by any inoculant but was lower in B500 silages versus others (276 vs. $386 \mathrm{~h}$ ). The conventional PCR confirmed the presence of similar populations of L. buchneri in all
\end{abstract}

Received September 9, 2010.

Accepted November 20, 2010.

${ }^{1}$ Corresponding author: kimsc@gnu.ac.kr

${ }^{2}$ Current address: Department of Animal Science, Institute of Agriculture and Life Sciences, Gyeongsang National University, Jinju 660-701, South Korea. silages. This may have contributed to the prolonged aerobic stability of all silages.

Key words: corn silage, inoculant, Lactobacillus buchneri, Propionibacterium

\section{INTRODUCTION}

Inoculants containing selected strains of lactic acid bacteria (LAB) have been developed to reduce the influence of epiphytic LAB on the outcome of ensiling forages. The principal function of homofermentative inoculants is to ensure a rapid and efficient fermentation of water-soluble carbohydrates (WSC) into lactic acid, a rapid decrease in $\mathrm{pH}$, and improved silage conservation with minimal fermentation losses (Weinberg et al., 1993). However, such inoculants have not increased aerobic stability in many studies (Muck and Kung, 2007). Rather, some have decreased aerobic stability (Moon et al. 1980) by enhancing the growth of spoilage yeasts. Inoculating forages at harvest with Lactobacillus buchneri improves the aerobic stability of silages (Muck, 1996; Taylor et al., 2002), likely because this organism converts lactic acid to acetic acid under anaerobic conditions (Oude Elferink et al., 2001). Recently, L. buchneri has been combined with homolactic bacteria to improve the aerobic stability and fermentation of silages (Kung et al., 2003). Driehuis et al. (2001) reported that L. buchneri alone or in combination with Pediococcus pentosaceus and Lactobacillus plantarum improved aerobic stability of grass silage, reduced yeast and mold counts, and had lower DM loss compared with the untreated silage. Other studies reported improved aerobic stability when combinations of homolactic and heterolactic inoculants were applied to sorghum (Filya, 2003) and corn (Huisden et al., 2009). However, Adesogan et al. (2004) reported that treating bermudagrass with $P$. pentosaceus and $L$. buchneri improved fermentation but did not improve aerobic stability because their control silage was more stable due to a butyric fermentation. Kleinschmit and Kung, Jr. (2006) stated that an inoculant containing $P$. pentosaceus and L. buchneri reduced yeast counts and improved aerobic stability in a manner that varied with the ensiling duration. Kang et al. (2009) demonstrated 
that effects of inoculants containing Lactobacillus casei and $L$. buchneri on aerobic stability of corn silage varied with the corn hybrid tested. Therefore, more research is needed on effects of combinations of $L$. buchneri and homolactic bacteria.

Propionic acid bacteria can ferment glucose and lactate to acetate and propionic acid (Moon, 1983), and a few studies have shown that such inoculants improved the aerobic stability of silage (Dawson et al., 1998; Filya et al., 2004). Effects of combinations of propionibacteria and homolactic bacteria on silage fermentation and aerobic stability are not well known. The objective of this study was to examine the effect of applying bacterial inoculants containing heterofermentative bacteria (L. buchneri) alone or homofermentative (P. pentosaceus) and heterofermentative bacteria (Propionibacteria freudenreichii or L. buchneri) together on the fermentation, quality, and aerobic stability of corn silage.

\section{MATERIALS AND METHODS}

\section{Forage and Treatments}

A corn hybrid (Vigoro 61R36; Royster Clark Inc., Greeley, CO) was grown in April 2006 at the Dairy Research Unit, University of Florida (latitude $30^{\circ} \mathrm{N}$ and longitude $82.5^{\circ} \mathrm{W}$; elevation: $61 \mathrm{~m}$ above sea level). The temperature range, total precipitation, and average humidity during the growing season were 4.2 to $39.3^{\circ} \mathrm{C}, 28 \mathrm{~cm}$, and $71 \%$, respectively. The crop was harvested in July 2006 at 35\% DM with a Claas Jaguar 850 (Claas of America, Columbus, IN) forage harvester. Forages were chopped to a theoretical cut length of 1.9 $\mathrm{cm}$ and treated with (1) deionized water (CON); (2) Biotal Plus II (B2), applied at $21.9 \mathrm{mg} / \mathrm{kg}$ of fresh forage to supply $1 \times 10^{5} \mathrm{cfu} / \mathrm{g}$ of Pediococcus pentosaceus 12455 and Propionibacteria freudenreichii; (3) Buchneri 40788 (BUC) applied at $8 \mathrm{mg} / \mathrm{kg}$ of fresh forage to supply $4 \times 10^{5} \mathrm{cfu} / \mathrm{g}$ of $L$. buchneri; (4) a combination inoculant, Buchneri 500 (B500), applied at $8 \mathrm{mg} / \mathrm{kg}$ of fresh forage to supply $1 \times 10^{5} \mathrm{cfu} / \mathrm{g}$ of $P$. pentosaceus 12455 and $4 \times 10^{5}$ L. buchneri 40788 , respectively. Inoculants were dissolved in $950 \mathrm{~mL}$ of deionized water and sprayed uniformly onto the forages under constant mixing. All inoculants were supplied by Lallemand Animal Nutrition (Milwaukee, WI). Four replicates of each treatment were weighed $(10 \mathrm{~kg})$ into polyethylene bags within 20-L mini silos, sealed, and stored for 575 $\mathrm{d}$ at ambient temperature $\left(25^{\circ} \mathrm{C}\right)$ in a covered barn. Dry matter recovery was calculated from the initial and final weights and the DM concentrations of the fresh and ensiled forage.

\section{Chemical Analysis}

Subsamples of each untreated fresh forage and each treated silage were collected, dried in a forced-air oven at $60^{\circ} \mathrm{C}$ for $48 \mathrm{~h}$, and ground to pass a 1-mm screen using a Wiley mill (A. H. Thomas, Philadelphia, PA). The chemical composition of samples from each replicate silo was measured in duplicate. Concentrations of NDF and ADF were measured using the method of Van Soest et al. (1991) in an Ankom 200 Fiber Analyzer (Ankom Technologies, Macedon, NY). Starch was determined using the procedure of Holm et al. (1986). The anthrone reaction assay (Ministry of Agriculture, Fisheries and Food, 1986) was used to quantify WSC. After silos were opened, corn silage samples also were analyzed for aerobic stability by placing thermocouple wires at the center of a bag containing $1 \mathrm{~kg}$ of silage, within an open-top polystyrene box. The silages were covered with 2 layers of cheesecloth to prevent drying. The thermocouple wires were connected to data loggers (Campbell Scientific Inc., North Logan, UT) that recorded the temperature every $30 \mathrm{~min}$ for $14 \mathrm{~d}$. Aerobic stability was denoted by the time $(\mathrm{h})$ before a $2^{\circ} \mathrm{C}$ rise in silage temperature above ambient temperature $\left(23^{\circ} \mathrm{C}\right)$. Silage subsamples from each silo were submitted to Dairyland Laboratories Inc. (Arcadia, WI) for analysis of yeast and mold counts using YM-11 agar (AOAC, 1995), VFA by HPLC (Canale et al., 1984), $\mathrm{pH}$ using a $\mathrm{pH}$ meter (Orion 710+; Thermo Fisher Scientific Inc., Waltham, MA), and ammonia-N by distillation (AOAC, 1995).

\section{DNA Extraction}

Silage samples $(50 \mathrm{~g})$ from each treatment were diluted with $100 \mathrm{~mL}$ of distilled water and macerated in a blender to obtain silage extract for further analysis. The DNA was extracted from the water extract using the phenol-chloroform method (Giraffa et al., 2000). A $1.5 \mathrm{~mL}$ aliquot of each water extract was centrifuged at $12,500 \times g$ for $5 \mathrm{~min}$, the supernatant was discarded and this step was repeated. The pellets were washed twice with Tris-EDTA buffer $(10 \mathrm{~m} M$ Tris- $\mathrm{HCl}, 0.1 \mathrm{mM}$ EDTA, pH 8.0), resuspended in $500 \mu \mathrm{L}$ of Tris-EDTAsaccharose buffer (50 $\mathrm{m} M$ Tris- $\mathrm{HCl}, 1 \mathrm{~m} M$ EDTA, $6.7 \%$ saccharose, $\mathrm{pH} 8.0$ ) followed by incubation at $37^{\circ} \mathrm{C}$ for $30 \mathrm{~min}$ with $200 \mu \mathrm{L}$ of lysozyme $(50 \mathrm{mg} / \mathrm{mL})$. This was followed by a second incubation at $56^{\circ} \mathrm{C}$ for $30 \mathrm{~min}$ with $15 \mu \mathrm{L}$ of proteinase $\mathrm{K}$, and a third incubation at $56^{\circ} \mathrm{C}$ overnight with $125 \mu \mathrm{L}$ of $\operatorname{SDS}(20 \% \mathrm{wt} / \mathrm{vol})$. The DNA was extracted by adding $200 \mu \mathrm{L}$ of phenol and chloroform, centrifuging at 7,000 $\times g$ for $5 \mathrm{~min}$ 
Table 1. Chemical composition of corn forages treated with or without bacterial inoculants before ensiling ${ }^{1}$

\begin{tabular}{lccccc}
\hline Item & CON & B2 & BUC & B500 & SEM \\
\hline DM, \% & 35.4 & 32.9 & 31.5 & 33.1 & 1.46 \\
NDF, \% of DM & 42.8 & 43.0 & 43.0 & 41.7 & 1.07 \\
ADF, \% of DM & 25.1 & 25.1 & 25.3 & 25.7 & 0.97 \\
Starch, \% of DM & 25.5 & 28.4 & 22.9 & 24.8 & 2.72 \\
\hline
\end{tabular}

Means in the same row with different superscripts differed $(P<$ $0.05)$.

${ }^{1} \mathrm{CON}=$ control, no inoculant; $\mathrm{B} 2=$ Pediococcus pentosaceus and Propionibacteria freudenreichii; BUC = Lactobacillus buchneri; B500 $=$ Pediococcus pentosaceus and L. buchneri.

at $4^{\circ} \mathrm{C}$, and transferred to a new tube. This step was repeated 3 times, followed by precipitation with cold $\left(-20^{\circ} \mathrm{C}\right)$ isopropanol $(600 \mu \mathrm{L})$ and centrifugation at $12,500 \times g$ for $30 \mathrm{~min}$ at $4^{\circ} \mathrm{C}$. A 1 - $\mathrm{mL}$ aliquot of ethanol $(70 \%)$ was added to the pelleted DNA and centrifuged at $12,500 \times g$ for $5 \mathrm{~min}$ at $4^{\circ} \mathrm{C}$. Purified DNA was dried and resuspended overnight at $4^{\circ} \mathrm{C}$ in $150 \mu \mathrm{L}$ of Tris-EDTA buffer. Ribonuclease HII $(1 \mu \mathrm{L} ; 5,000 \mathrm{U} /$ $\mathrm{mL}$; New England BioLabs, Ipswich, MA) was added to resuspended DNA, and after incubation at $37^{\circ} \mathrm{C}$ for $1 \mathrm{~h}$, DNA samples were stored at $-20^{\circ} \mathrm{C}$ until use.

\section{Conventional PCR Conditions}

The PCR was performed to amplify a region of the bacterial $16 \mathrm{~S}$ rRNA gene of L. buchneri with the forward primer LBR2 that corresponds to the region from base 186 to 215 (5'-GAAACAGGTGCTAATACCGTATAACAACCA-3') and the reverse primer LBR 1 that corresponds to the region from base 316 to 345 (5'-CGCCTTGG-TAGGCCGTTACCTTACCAACA-3'; GenoMechanix LLC, Gainesville, FL). The expected product size was $159 \mathrm{bp}$. A touchdown PCR was done in a PTC-100 programmable thermal controller (MJ Research Inc., Waltham, MA) to reduce the incidence of false product formation, enhance correct annealing, and increase the specificity of the amplification (Kidd and Ruano, 1995). The annealing temperature was set at $61^{\circ} \mathrm{C}$ for the first cycle and reduced by $0.5^{\circ} \mathrm{C}$ per cycle for the next 9 cycles to reach a final melting temperature $\left(T_{\mathrm{m}}\right)$ of $56^{\circ} \mathrm{C}$. The previous melting temperature was used for the remaining 20 cycles. An extension time of $30 \mathrm{~s}$ at $72^{\circ} \mathrm{C}$ was used, with a final extension of $7 \mathrm{~min}$ and hold at $4^{\circ} \mathrm{C}$. Amplification was done in a standard reaction mixture containing $16.75 \mu \mathrm{L}$ of $\mathrm{H}_{2} \mathrm{O}, 2.5 \mu \mathrm{L}$ of $10 \times$ Taq buffer advanced (5 Prime), $1 \mu \mathrm{L}$ of each primer, $2.5 \mu \mathrm{L}$ of $2 \mathrm{~m} M$ dNTP (Thermo Fisher Scientific Inc.), $0.25 \mu \mathrm{L}$ of Taq polymerase (5 $\mathrm{U} / \mu \mathrm{L} ; 5$ Prime), and $2 \mu \mathrm{L}$ of the template. Electrophoresis was conducted on $2.0 \%$ agarose gel stained with ethidium bromide, and DNA was visualized under UV light and photographed (Sambrook et al., 1989).

\section{Statistical Analysis}

The data were analyzed as a completely randomized design using the GLM procedure of SAS (v. 9.2 SAS Institute Inc., Cary, NC). The general model was $Y_{i j}=$ $\mu+T_{i}+e_{i j}$, where $Y_{i j}=$ response variable, $\mu=$ overall mean, $T=$ effect of treatment $i$, and $e_{i j}=$ error term. The F-protected least significant difference test was used to compare least squares means and significance was declared at $P<0.05$.

\section{RESULTS AND DISCUSSION}

The chemical composition of the corn forages was normal for silage hybrids produced in Florida (Table 1; Huisden et al., 2009; Kang et al., 2009). The control silage had the greatest DM concentration, but other chemical components did not differ among the forages. Corn forage treated with B2 had a lower DM concentration than B500 and CON silages, whereas CP concentration was greater in $\mathrm{CON}$ and $\mathrm{B} 2$ silages than in the others (Table 2). As expected, the WSC concentrations of all silages were reduced during the fermentation. The B500 silage had the greatest $(P<0.05)$ residual WSC concentration (1.49 vs. $1.18 \% \mathrm{DM})$, suggesting that plant sugars were less extensively fermented by the bacteria in this inoculant compared with those in others. In contrast, Filya (2003) reported that CON and L. plantarum-inoculated corn silages had greater $(P<0.05)$ residual WSC than silages inoculated with L. buchneri alone or L. buchneri and L. plantarum together. High residual WSC concentrations in silages are desirable because they reflect a more efficient fermentation in the silo and indicate greater availability of energy-yielding substrates for ruminal microbes, but such concentrations also can induce spoilage yeast growth.

All $\mathrm{pH}$ values were within the range of 3.8 to 4.1 (Table 3), which reflects adequate fermentation for restricting the growth of undesirable microorganisms like Clostridia. Dry matter loss was lower in BUC silages compared with CON and B2 silages (5.0 vs. 14.3\%). Control and B2 silages had greater $\mathrm{pH}$ and lower lactic acid concentration than BUC and B500 silages. The combination of the greater total acid and lactate concentrations and lower $\mathrm{pH}$ of BUC silages explain the lower DM loss from this silage. Despite having $\mathrm{pH}$ and lactate concentration similar to BUC, the B500 treatment did not reduce DM loss because it had similar total acid concentration to the control. Propionic acid 
Table 2. Effect of bacterial inoculants on the chemical composition of corn silages ${ }^{1}$

\begin{tabular}{lcccccc}
\hline Item & CON & B2 & BUC & B500 & SEM & $P$-value \\
\hline DM, \% & 31.4 & 29.9 & 31.2 & 31.7 & 0.84 & 0.09 \\
CP, \% of DM & $10.5^{\mathrm{a}}$ & $10.3^{\mathrm{a}}$ & $9.86^{\mathrm{b}}$ & $9.86^{\mathrm{b}}$ & 0.31 & 0.03 \\
NDF, \% of DM & $44.4^{\mathrm{a}}$ & $43.2^{\mathrm{ab}}$ & $42.3^{\mathrm{b}}$ & $42.0^{\mathrm{b}}$ & 1.06 & 0.04 \\
ADF, \% of DM & 27.2 & 27.4 & 26.2 & 26.6 & 0.99 & 0.42 \\
Starch, \% of DM & 26.1 & 27.8 & 28.3 & 25.2 & 2.81 & 0.41 \\
Water-soluble carbohydrate, \% of DM & $1.22^{\mathrm{b}}$ & $1.14^{\mathrm{b}}$ & $1.18^{\mathrm{b}}$ & $1.49^{\mathrm{a}}$ & 0.12 & 0.01 \\
\hline
\end{tabular}

${ }^{\mathrm{a}, \mathrm{b}}$ Means in the same row with different superscripts differed $(P<0.05)$.

${ }^{1} \mathrm{CON}=$ control, no inoculant; $\mathrm{B} 2=$ Pediococcus pentosaceus and Propionibacteria freudenreichii; $\mathrm{BUC}=$

Lactobacillus buchneri; $\mathrm{B} 500=$ Pediococcus pentosaceaus and L. buchneri.

concentration was greater in $\mathrm{CON}$ and $\mathrm{B} 2$ silages than BUC and B500 silages. Acetic acid concentration was greatest in the $\mathrm{B} 2$ silage ( 6.46 vs. $4.23 \% \mathrm{DM})$, lowest in the B500 silage, and intermediate in CON and BUC silages. The B500 silage had the greatest lactic:acetic acid ratio (1.54 vs. 0.41$)$.

The fermentation results of the CON, BUC, and B500 silages were unusual. Normally, untreated corn silage undergoes a homolactic fermentation resulting in relatively low $\mathrm{pH}$ values $(<4.0)$ due to high concentrations of lactate and low concentrations of acetate and propionate (Rooke and Hatfield, 2003). In contrast, the CON silage had among the highest $\mathrm{pH}$ values, lowest lactate concentrations, and highest acetate and propionate concentrations. These results suggest that the fermentation was dominated by heterolactic bacteria. Furthermore, the homolactic bacteria in B2 and B500 did not dominate the fermentation sufficiently to result in greater lactate concentrations and lower DM loss relative to those in the CON silage. Results of inoculation with BUC and B500 were atypical in that application of L. buchneri to corn forage usually increases the concentration of acetate and reduces the lactate concentration
(Ranjit and Kung, 2000; Filya, 2003; Hu et al., 2009). This could be due to the presence of high concentrations of epiphytic L. buchneri that naturally occurred in the control silages. The conventional PCR analysis was performed to examine this theory. It revealed the presence of similarly sized bands representing epiphytic populations of $L$. buchneri in all silages irrespective of the fact that inoculant-sourced $L$. buchneri was only added in 2 (B500 and BUC) of the 5 treatments (Figure 1). This may explain why inoculants containing $L$. buchneri did not have normal effects on the fermentation. Factors predisposing to high natural growth of epiphytic populations of $L$. buchneri on corn forages or silages are unknown and warrant further research.

Propionic acid bacteria can ferment glucose and lactate to acetate and propionate (Moon, 1983); therefore, the presence of Propionibacteria in B2 partly explains the greater acetate concentration and numerically greater propionate concentration of $\mathrm{B} 2$ silages relative to $\mathrm{CON}$ silages. However, inoculation with Propionibacteria has had equivocal effects on the propionic acid concentration of silages, with few studies showing positive effects (Dawson et al., 1998) and many others showing little to

Table 3. Effect of bacterial inoculants on DM losses, fermentation indices, yeast and mold counts, and aerobic stability of corn silages ${ }^{1}$

\begin{tabular}{lcccccc}
\hline Item & CON & B2 & BUC & B500 & SEM & $P$-value \\
\hline DM loss, \% & $14.9^{\mathrm{a}}$ & $13.6^{\mathrm{ab}}$ & $5.0^{\mathrm{c}}$ & $8.2^{\mathrm{ab}}$ & 3.92 & 0.016 \\
$\mathrm{pH}$ & $4.10^{\mathrm{a}}$ & $4.06^{\mathrm{a}}$ & $3.90^{\mathrm{b}}$ & $3.80^{\mathrm{b}}$ & 0.05 & $<0.001$ \\
$\mathrm{NH}_{3}$-N, \% of CP & 8.25 & 9.68 & 8.92 & 8.01 & 1.15 & 0.28 \\
Total acids, \% of DM & $7.15^{\mathrm{b}}$ & $8.88^{\mathrm{a}}$ & $8.40^{\mathrm{a}}$ & $7.30^{\mathrm{b}}$ & 0.58 & 0.005 \\
Lactic acid, \% of DM & $1.56^{\mathrm{b}}$ & $1.31^{\mathrm{b}}$ & $3.34^{\mathrm{a}}$ & $4.17^{\mathrm{a}}$ & 0.72 & 0.001 \\
Acetic acid, \% of DM & $4.85^{\mathrm{b}}$ & $6.46^{\mathrm{a}}$ & $4.88^{\mathrm{b}}$ & $2.97^{\mathrm{c}}$ & 0.59 & $<0.001$ \\
Propionic acid, \% of DM & $0.72^{\mathrm{a}}$ & $1.09^{\mathrm{a}}$ & $0.17^{\mathrm{b}}$ & $0.08^{\mathrm{b}}$ & 0.16 & $<0.001$ \\
Butyric acid, \% of DM & 0.01 & 0.01 & 0.01 & 0.07 & 0.06 & 0.47 \\
Isobutyric acid, \% of DM & 0.01 & 0.01 & 0.01 & 0.01 & 0.00 & - \\
Ethanol, \% of DM & 0.01 & 0.10 & 0.01 & 0.01 & 0.07 & 0.28 \\
Lactic:acetic acid ratio & $0.33^{\mathrm{b}}$ & $0.21^{\mathrm{b}}$ & $0.69^{\mathrm{b}}$ & $1.54^{\mathrm{a}}$ & 0.35 & 0.001 \\
Yeasts, log cfu/g & $<3.00$ & $<3.00$ & $<3.00$ & $<3.00$ & 0.00 & - \\
Molds, log cfu/g & 3.4 & 3.67 & 4.15 & 3.75 & 0.71 & 0.54 \\
Aerobic stability, h & $390^{\mathrm{a}}$ & $390^{\mathrm{a}}$ & $381^{\mathrm{a}}$ & $276^{\mathrm{b}}$ & 53 & 0.07 \\
\hline
\end{tabular}

${ }^{\mathrm{a}-\mathrm{c}}$ Means in the same row with different superscripts differed $(P<0.05)$.

${ }^{1} \mathrm{CON}=$ control, no inoculant; $\mathrm{B} 2=$ Pediococcus pentosaceus and Propionibacteria freudenreichii; $\mathrm{BUC}=$ Lactobacillus buchneri; $\mathrm{B} 500=$ P. pentosaceaus and L. buchneri. 


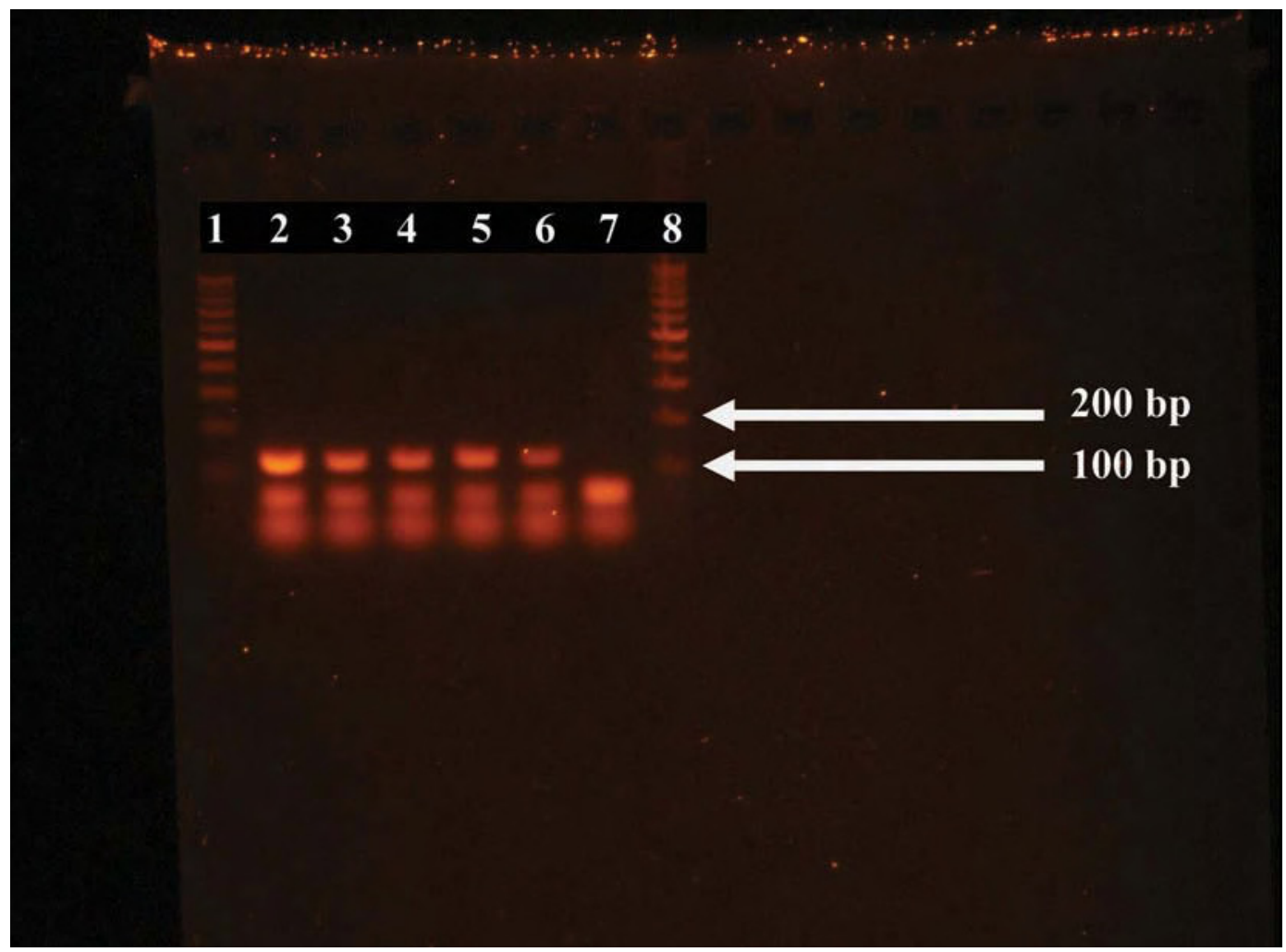

Figure 1. Gel electrophoresis analysis after PCR amplification of DNA from silages treated with or without inoculants: lanes 1 and $8=$ DNA ladder/marker (Promega Corp., Madison, WI); lane $2=$ pure culture of Lactobacillus buchneri; lane $3=\mathrm{CON}$, untreated control; lane $4=\mathrm{B} 2$, Pediococcus pentosaceus and Propionibacteria freudenreichii; lane $5=\mathrm{BUC}$, L. buchneri; lane $6=\mathrm{B} 500$, P. pentosaceus plus L. buchneri; lane 7 $=$ negative control. The expected product size was $159 \mathrm{bp}$. Color version available in the online PDF.

no effect (Higginbotham et al., 1998; Kung and Ranjit, 2001; Pedroso et al., 2010). Consequently, such bacteria have not usually increased aerobic stability (Weinberg et al., 1995; Higginbotham et al., 1998; Pedroso et al., 2010).

Yeast and mold counts were less than the threshold $\left(10^{5}\right)$ typically associated with silage spoilage (Pahlow and Zimmer, 1985; O'Kiely et al., 1987) and did not differ among treatments (Table 3). Consequently, all silages were stable for long periods $(>250 \mathrm{~h})$ even though B500 silages were less stable than the others. That application of L. buchneri inoculants did not increase the aerobic stability or decrease the yeast counts relative to those of untreated silages contradicts various reports (Kleinschmit and Kung, 2006; Hu et al., 2009; Huisden et al., 2009; Pedroso et al., 2010). This is likely because of the high population of $L$. buchneri in all silages. The greater deterioration of the B500 silage, which had one of the highest lactate concentrations, reflects the relatively low antifungal property of lactate. In fact, lactate serves as a substrate for several spoilage yeasts such as those of the genera Candida and Pichia spp. (Pahlow et al., 2003). Acetate, butyrate, and propionate are the main antifungal acids in silages (Moon, 1983) and the total concentration of these acids was lower in the B500 silage than in others. Weinberg et al. (1993) reported that high levels of residual WSC, combined with high lactate concentrations and insufficient concentrations of antifungal VFA in silages inoculated with homofermentative LAB were associated with aerobic spoilage. The greater residual WSC concentration and lower total antifungal acid concentration may have made the B500 silage more susceptible to deterioration than others in this study.

\section{CONCLUSIONS}

The BUC and B500 silages had a more homolactic fermentation evidenced by greater lactate concentration and lower $\mathrm{pH}$ than other silages. However, only BUC application reduced DM losses relative to the control treatment. Aerobic stability was generally high $(>250$ h) and was not improved by inoculant application. Therefore, the BUC inoculant was the best treatment under the conditions of this study. The conventional PCR analysis confirmed the presence of similarly sized 
bands representing populations of $L$. buchneri in all treatments and this likely explains the prolonged aerobic stability of all silages.

\section{REFERENCES}

Adesogan, A. T., N. Krueger, M. B. Salawu, D. B. Dean, and C. R. Staples. 2004. The influence of treatment with dual purpose bacterial inoculants or soluble carbohydrates on the fermentation and aerobic stability of bermudagrass. J. Dairy Sci. 87:3407-3416.

AOAC. 1995. Official Methods of Analysis. Vol. I. 16th ed. Association of Official Analytical Chemists, Washington, DC.

Canale, A., M. E. Valente, and A. Ciotti. 1984. Determination of volatile carboxylic acids (C1-C5i) and lactic acid in aqueous acid extracts of silage by high performance liquid chromatography. J. Sci. Food Agric. 35:1178-1182.

Dawson, T. E., S. R. Rust, and M. T. Yokoyama. 1998. Improved fermentation and aerobic stability of ensiled high moisture corn with the use of Propionibacterium acidipropionici. J. Dairy Sci. 81:1015-1021.

Driehuis, F., S. J. W. H. Oude Elferink, and P. G. Van Wikselaar. 2001. Fermentation characteristics and aerobic stability of grass silage inoculated with Lactobacillus buchneri, with or without homofermentative lactic acid bacteria. Grass Forage Sci. 56:330-343.

Filya, I. 2003. The effect of Lactobacillus buchneri and Lactobacillus plantarum on the fermentation, aerobic stability, and ruminal degradability of low dry matter corn and sorghum silages. J. Dairy Sci. 86:3575-3581.

Filya, I., E. Sucu, and A. Karabulut. 2004. The effect of Propionibacterium acidipropionici, with or without Lactobacillus plantarum, on the fermentation and aerobic stability of wheat, sorghum and maize silages. J. Appl. Microbiol. 97:818-826.

Giraffa, G., L. Rossetti, and E. Neviani. 2000. An evaluation of chelexbased DNA purification protocols for the typing of lactic acid bacteria. J. Microbiol. Methods 42:175-184.

Higginbotham, G. E., S. C. Mueller, K. K. Bolsen, and E. J. DePeters. 1998. Effects of inoculants containing propionic acid bacteria on fermentation and aerobic stability of corn silage. J. Dairy Sci. 81:2185-2192.

Holm, J. I., I. Bjorck, A. Drews, and N. G. Asp. 1986. A rapid method for the analysis of starch. Starch/Die Stärke 7:224-226.

Hu, W., R. J. Schmidt, E. E. McDonell, C. M. Klingerman, and L. Kung Jr.. 2009. The effect of Lactobacillus buchneri 40788 or Lactobacillus plantarum MTD-1 on the fermentation and aerobic stability of corn silages ensiled at two dry matter contents. J. Dairy Sci. 92:3907-3914.

Huisden, C. M., A. T. Adesogan, S. C. Kim, and T. Ososanya. 2009. Effect of applying molasses or inoculants containing homofermentative or heterofermentative bacteria at two rates on the fermentation and aerobic stability of corn silage. J. Dairy Sci. 92:690697.

Kang, T. W., A. T. Adesogan, S. C. Kim, and S. S. Lee. 2009. Effects of an esterase-producing inoculant on fermentation, aerobic stability, and neutral detergent fiber digestibility of corn silage. J. Dairy Sci. 92:732-738.

Kidd, K. K., and G. Ruano. 1995. Optimizing PCR. Pages 1-22 in PCR, A Practical Approach. M. J. McPherson, B. D. Hames, and G. R. Taylor, ed. Oxford University Press, Oxford, UK.

Kleinschmit, D. H., and L. Kung, Jr. 2006. The effects of Lactobacillus buchneri 40788 and Pediococcus pentosaceus R1094 on the fermentation of corn silage. J. Dairy Sci. 89:3999-4004.

Kung, L. Jr., and N. K. Ranjit. 2001. The effect of Lactobacillus buchneri and other additives on the fermentation and aerobic stability of barley silage. J. Dairy Sci. 84:1149-1155.
Kung, L. Jr., C. C. Taylor, M. Lynch, and J. M. Neylon. 2003. The effect of treating alfalfa with Lactobacillus buchneri 40788 on silage fermentation, aerobic stability, and nutritive value for dairy cows. J. Dairy Sci. 86:336-343.

Ministry of Agriculture, Fisheries, and Food. 1986. The Analysis of Agricultural Materials. Reference Book 427. HMSO, London, UK.

Moon, N. J. 1983. Inhibition of the growth of acid tolerant yeasts by acetate, lactate and propionate and their synergistic mixtures. J. Appl. Bacteriol. 55:454-460.

Moon, N. J., L. O. Ely, and E. M. Sudweeks. 1980. Aerobic deterioration of wheat, lucerne and maize silage prepared with Lactobacillus acidophilus and a Candida spp. J. Appl. Bacteriol. 49:75-87.

Muck, R. E. 1996. A lactic acid bacteria strain to improve aerobic stability of silages. Pages 42-43 in 1996 Research Summaries. US Dairy Forage Research Center, Madison, WI.

Muck, R. E., and L. Kung, Jr. 2007. Silage production. Pages 617-633 in Forages: The Science of Grassland Agriculture. Vol. II. 6th ed. R. F. Barnes, C. J. Nelson, K. J. Moore, and M. Collins, ed. Blackwell Publishing, Ames, IA.

O'Kiely, P., R. E. Muck, and P. L. O'Connor. 1987. Aerobic deterioration of alfalfa and maize silage. J. Irish Grassl. Anim. Prod. Assoc. 21:145.

Oude Elferink, S. J. W. H., J. Krooneman, J. C. Gottschal, S. F. Spoelstra, F. Faber, and F. Driehuis. 2001. Anaerobic conversion of lactic acid to acetic acid and 1,2-propanediol by Lactobacillus buchneri. Appl. Environ. Microbiol. 67:125-132.

Pahlow, G., R. E. Muck, F. Driehuis, S. J. W. H. Oude Elferink, and S. F. Spoelstra. 2003. Microbiology of ensiling. Pages 31-93 in Silage Science and Technology (Agronomy Series No. 42). D. R. Buxton, R. E. Muck, and H. J. Harrison, ed. American Society of Agronomy. Madison, WI.

Pahlow, G., and E. Zimmer. 1985. Effect of a lactobacillus inoculant on fermentation and aerobic stability of grass silage. Pages 24-31 in Proc. 15th Intl. Grassld. Congress, Kyoto, Japan. Institute of Grassland and Forage Research, FAL, Braunschweig, Fed. Rep. Germany.

Pedroso, A. F., A. T. Adesogan, O. C. M. Queiroz, and S. K. Williams. 2010. Control of Escherichia coli O157:H7 in corn silage with or without various inoculants: Efficacy and mode of action. J. Dairy Sci. 93:1098-1104.

Ranjit, N. K., and L. Kung Jr.. 2000. The effect of Lactobacillus buchneri, Lactobacillus plantarum, or a chemical preservative on the fermentation and aerobic stability of corn silage. J. Dairy Sci. $83: 526-535$.

Rooke, J. A., and R. D. Hatfield. 2003. Biochemistry of Ensiling. Pages 95-139 in Silage Science and Technology (Agronomy Series No. 42). D. R. Buxton, R. E. Muck, and H. J. Harrison, ed. American Society of Agronomy, Madison, WI.

Sambrook, J., E. F. Fritsch, and T. Maniatis. 1989. Molecular Cloning: A Laboratory Manual. Cold Spring Harbor Laboratory, Cold Spring Harbor, NY.

Taylor, C. C., N. J. Ranjit, J. A. Mills, J. M. Neylon, and L. Kung, Jr.. 2002. The effect of treating whole-plant barley with Lactobacillus buchneri 40788 on silage fermentation, aerobic stability, and nutritive value for dairy cows. J. Dairy Sci. 85:1793-1800.

Van Soest, P. J., J. B. Robertson, and B. A. Lewis. 1991. Methods for dietary fiber, neutral detergent fiber, and nonstarch polysaccharides in relation to animal nutrition. J. Dairy Sci. 74:3583-3597.

Weinberg, Z. G., G. Ashbell, K. K. Bolsen, G. Pahlow, Y. Hen, and A. Azrieli. 1995. The effect of a propionic acid bacterial inoculants applied at ensiling, with or without lactic acid bacteria, on the aerobic stability of pearl millet and maize silages. J. Appl. Bacteriol. 78:430-436.

Weinberg, Z. G., G. Ashbell, Y. Hen, and A. Azrieli. 1993. The effect of applying lactic acid bacteria at ensiling on the aerobic stability of silages. J. Appl. Bacteriol. 75:512-518. 